\title{
The Provision of Mobile Services in US Urban Libraries
}

\section{ABSTRACT}

To determine the present situation regarding services provided to mobile users in US urban libraries, the authors surveyed 138 Urban Libraries Council members utilizing a combination of mobile visits, content analysis, and librarian interviews. The results show that nearly 95\% of these libraries have at least one mobile website, mobile catalog, or mobile app. The libraries actively applied new approaches to meet each local community's remote-access needs via new technologies, including app download links, mobile reference services, scan ISBN, location navigation, and mobile printing. Mobile services that libraries provide today are timely, convenient, and universally applicable.

\section{INTRODUCTION}

The mobile internet has had a major impact on people's lives and on how information is found located and accessed. Today, library patrons are untethered from and free of the limitations of the desktop computer. ${ }^{1}$ The popularity of mobile devices has changed the relationship between libraries and patrons. Mobile technology allows libraries to have the kind of connectivity with their patrons that did not exist previously.

Patrons no longer think that it is necessary for them to be physically in the library building to use library services, and they are eager to obtain $24 / 7$ access to library resources anywhere using their mobile devices. Mobile patrons need mobile libraries to provide them with services. In other words, "patrons want to have a library in their pocket." ${ }^{2}$ As a result, libraries around the world are exploring and developing mobile services.

According to the State of America's Libraries 2017 report by the American Library Association, the 50 US states, the District of Columbia, and outlying territories have 8,895 public library administrative units (as well as 7,641 branches and bookmobiles). The vital role public libraries play in their communities has also expanded. ${ }^{3}$ As part of the main role of public libraries, US urban libraries need to embrace the developmental trend of the mobile internet to better serve their communities. The provision of mobile services in US urban libraries is worthy of study and is of great significance as a model for how other public libraries plan and implement their mobile services.

Ya Jun Guo (yadon0619@hotmail.com) is Associate Professor of Information and Library Science at Zhengzhou University of Aeronautics, China. Yan Quan Liu (liuy1@southernct.edu) is Professor of Information and Library Science at Southern Connecticut State University. Arlene Bielefield (bielefielda1@southernct.edu) is Professor in Information and Library Science at Southern Connecticut State University. 


\section{LITERATURE REVIEW}

\section{Definition and Types of Mobile Devices and Mobile Services}

As early as 1991, Mark Weiser proposed "ubiquitous computing," pointing out how people could obtain and handle information at anytime, anywhere, and in any way. ${ }^{4}$ With this expectation, the possibilities of using personal digital assistants (PDAs) as mobile web browsers were researched in $1995 .{ }^{5}$ In combination with a wireless modem, library users are able to use PDAs to access information services whenever they are needed. Today, mobile devices are generally defined as units small enough to carry around in a pocket, falling into the categories of PDAs, mobile phones, and personal media players. ${ }^{6}$ For many researchers, laptops are not included in the definition of mobile devices. Although wireless laptops purportedly offer the opportunity to go "anywhere in the home," laptops are generally used in a small set of locations, rather than moving fluidly through the home; wireless laptops are portable, but not mobile. ${ }^{7}$

In contrast, Lippincott suggested that mobile devices should include laptops, netbooks, notebook computers, cell phones, audio players such as MP3 players, cameras, and other items. ${ }^{8}$ According to the "Mobile Strategy Report" by the California Digital Library, mobile phones, e-readers, MP3 players, tablets, gaming devices, and PDAs are common mobile devices. ${ }^{9}$ Each mobile device has its own characteristics and the potential to connect to the internet from anywhere with a Wi-Fi network, driving widespread use and thus the provision of library mobile services.

Mobile services are services libraries offer to patrons via their mobile devices. These services as described herein comprise two categories: traditional library services modified to be available via mobile devices and services created for mobile devices. ${ }^{10}$ Pope et al. listed several mobile services, including SMS or text-messaging services, the My Info Quest Project, digital collections, audiobooks, applications, and mobile-friendly websites. ${ }^{11}$ The California Digital Library pointed out that a growing number of university and public libraries are offering mobile services. Libraries are creating mobile versions of library websites, using text messaging to communicate with patrons, developing mobile catalog searching, providing access to resources, and creating new tools and services, particularly for mobile devices. ${ }^{12}$

The most recognized mobile services in university libraries are mobile sites, mobile apps, mobile OPACs, mobile access to databases, text messaging services, QR codes, augmented reality, and ebooks. ${ }^{13}$ Both academic and public libraries' use of Web 2.0 applications and services include blogs, wikis, phone apps, QR codes, mash-ups, video or audio sharing, customized webpages, social media and social networking, and types of social tagging. ${ }^{14}$

This study focuses on the two most common mobile devices, mobile phones and tablets, and on the services provided to library patrons and local communities through mobile websites, mobile apps, and mobile catalogs.

\section{Status of Mobile Services in US Libraries}

Mobile devices present a new and exciting opportunity for libraries of all types to provide information to people of all ages on the go, wherever they are. ${ }^{15}$ It is generally observed that there is an increased use of mobile technology in the library environment. 
Librarians see their users increasingly using mobile phones instead of laptops and desktop computers to search the catalog, check the library's opening hours, and maintain contact with library staff. ${ }^{16}$ In an earlier investigation of 766 librarians, Spires found that there was very little demand for services for mobile devices as of August 2007. At that time, relatively few libraries (18\%) purchased content specifically for wireless handheld device use, and very few libraries (15\%) reformatted content for these devices. ${ }^{17}$ However, a survey of public libraries completed by the American Library Association between September and November 2011 indicated interesting changes:

$15 \%$ of library websites are optimized for mobile devices, and $12 \%$ of libraries use scanned codes (e.g. QR codes), and 7\% of libraries have developed smartphone applications for access to library services; $36 \%$ of urban libraries have websites optimized for mobile devices, compared to $9 \%$ of rural libraries; $76 \%$ of libraries offer access to e-books; $70 \%$ of libraries use social networking tools such as Facebook. ${ }^{18}$

Later studies revealed more significant changes. 99 Association of Research Libraries member libraries were surveyed in 2012 to identify how many had optimized at least some services for the mobile web. Apps were not investigated. The result showed that 83 libraries (84\%) had a mobile website. ${ }^{19}$

A study in 2015 by Liu and Briggs showed that the top 100 university libraries in the United States offered one or more mobile services, with mobile websites, mobile access to the library catalog, mobile access to the library's databases, e-books, and text messaging services being the most common. QR codes and augmented reality were less common. ${ }^{20}$

Kim noted that "libraries are acknowledging that people expect to do just about everything on mobile devices and that more and more people are now using a mobile device as their primary access point for the Web."21 Although librarians may have previously underestimated what people wanted to do using mobile devices, there is a growing understanding of the potential of these access points.

\section{RESEARCH DESIGN}

\section{Survey Samples}

While a growing number of users tend to access information remotely, urban libraries, as the most popular public-sector institutions and community centers, are facing great challenges in addressing the growing need for mobile services. The Urban Libraries Council (ULC) (https://www.urbanlibraries.org), as an authoritative source founded in 1971, is the premier membership association of North America's leading public library systems. ULC's member libraries are in communities throughout the United States and Canada, comprising a mix of institutions with varying revenue sources and governance structures, and serving communities with populations of differing sizes.

ULC's website lists 145 US and Canadian urban libraries. Since this study focused only on US urban libraries, 138 libraries were chosen as the study targets, and all were examined. 
Table 1. The survey and examples of survey results.

\begin{tabular}{|c|c|c|c|c|}
\hline Contents & Options & $\begin{array}{l}\text { Example } \\
\text { No.1: } \\
\text { Pima } \\
\text { County } \\
\text { Public } \\
\text { Library }\end{array}$ & $\ldots$ & $\begin{array}{l}\text { Example } \\
\text { No.138: } \\
\text { Milwaukee } \\
\text { Public } \\
\text { Library }\end{array}$ \\
\hline $\begin{array}{l}\text { Components } \\
\text { of mobile } \\
\text { websites }\end{array}$ & $\begin{array}{l}1 \text { Account login; } 2 \text { Catalog search; } 3 \text { Contact us; } 4 \\
\text { Downloadables; } 5 \text { Events; } 6 \text { Interlibrary loan; } 7 \text { Kids \& } \\
\text { teens; } 8 \text { Locations and hours; } 9 \text { Meeting room; } 10 \\
\text { Recent arrivals; } 11 \text { Recommendations; } 12 \text { Social } \\
\text { media; } 13 \text { Suggest a purchase; } 14 \text { Support }\end{array}$ & $\begin{array}{l}1,2,3,4,5 \\
7,8,9,10 \\
12,13,14\end{array}$ & & $\begin{array}{l}1,2,3,4,5 \\
7,8,9,12 \\
13,14\end{array}$ \\
\hline $\begin{array}{l}\text { Components of } \\
\text { mobile apps }\end{array}$ & $\begin{array}{l}1 \text { Account login; } 2 \text { Barcode Wallet; } 3 \text { Bestsellers; } 4 \\
\text { Catalog search; } 5 \text { Contact us; } 6 \text { Downloadables; } 7 \\
\text { Events; } 8 \text { Full website; } 9 \text { Interlibrary loan; } 10 \text { Just } \\
\text { ordered; } 11 \text { Kids \& teens; } 12 \text { Locations and hours; } 13 \\
\text { Meeting room; } 14 \text { My Bookshelf; } 15 \text { My library; } 16 \text { Pay } \\
\text { fines; } 17 \text { Popular this week; } 18 \text { Recent arrivals; } 19 \\
\text { Recommendations; } 20 \text { Scan ISBN; } 21 \text { Social media; } 22 \\
\text { Suggest a purchase; } 21 \text { Support }\end{array}$ & $\begin{array}{l}1,4,5,6,7 \\
8,12,15 \\
18,20,21\end{array}$ & & $\begin{array}{l}1,4,5,6,7 \\
8,12,17,20 \\
21\end{array}$ \\
\hline $\begin{array}{l}\text { Mobile } \\
\text { reference } \\
\text { services }\end{array}$ & 1 Chat/IM; 2 Social Medias; 3 Text/SMS; 4 Web Form & -- & & $1,3,4$ \\
\hline Social media & $\begin{array}{l}1 \text { Blog; } 2 \text { Facebook; } 3 \text { Flickr; } 4 \text { Goodreads; } 5 \text { Google+; } \\
6 \text { Instagram; } 7 \text { LinkedIn; } 8 \text { Pinterest; } 9 \text { Tumblr; } 10 \\
\text { Twitter; } 11 \text { YouTube }\end{array}$ & $\begin{array}{l}1,2,3,6,8 \\
10,11\end{array}$ & & $1,2,6,8,10$ \\
\hline $\begin{array}{l}\text { Mobile } \\
\text { reservation } \\
\text { services }\end{array}$ & $\begin{array}{l}1 \text { Reserve a computer; } 2 \text { Reserve a librarian; } 3 \\
\text { Reserve a meeting room; } 4 \text { Reserve a museum pass; } 5 \\
\text { Reserve a study room; } 6 \text { Reserve exhibit space }\end{array}$ & -- & & 3. \\
\hline $\begin{array}{l}\text { Mobile } \\
\text { printing }\end{array}$ & $\begin{array}{l}1 \text { Mobile printing; } 2 \text { No mobile/ Wi-Fi printing; } 3 \mathrm{Wi} \text { - } \\
\text { Fi printing }\end{array}$ & 3. & & 2. \\
\hline $\begin{array}{l}\text { Apps or } \\
\text { databases }\end{array}$ & $\begin{array}{l}1 \text { Axis 360; } 2 \text { BiblioBoard; } 3 \text { BookFlix;4 Brainfuse; } 5 \\
\text { Career Transitions; } 6 \text { Cloud Library; } 7 \text { Driving } \\
\text {-Tests.org; } 8 \text { EBSCOhost; } 9 \text { Flipster; } 10 \text { Freading; } 11 \\
\text { Freegal; } 12 \text { Gale Virtual; } 13 \text { Hoopla; } 14 \text { Instant Flix; } 15 \\
\text { Learning Express; } 16 \text { Lynda.com; } 17 \text { Mango } \\
\text { Languages; } 18 \text { Master FILE; } 19 \text { Morningstar; } 20 \text { New } \\
\text { York Times; } 21 \text { NoveList; } 22 \text { One Click Digital; } 23 \\
\text { Overdrive; 24 Reference USA; 25 Safari; } 26 \text { Tumble } \\
\text { Book; } 27 \text { Tutor.com; } 28 \text { World Book; } 29 \text { WorldCat; } 30 \\
\text { Zinio. }\end{array}$ & $\begin{array}{l}4,11,14 \\
22,23,26 \\
28,30\end{array}$ & & $\begin{array}{l}4,8,11,12 \\
13,15,17 \\
18,19,21 \\
23,24,30\end{array}$ \\
\hline
\end{tabular}




\section{Survey Methods}

As mobile services are offered basically via wireless systems and mobile devices, a combination of research methods, including mobile website visits, content analysis, and librarian interviews, were applied for data collection. Specifically, librarian interviews were employed as a verification and supplemental process to ensure that survey data were accurate and exhaustive.

First, the authors utilized an iPhone, an Android mobile phone, and an iPad to access the websites of the 138 US urban libraries in the study sample to ascertain if these libraries have mobile websites or mobile catalogs and whether the platforms are operated properly. Then the authors checked whether these libraries have mobile apps that can be downloaded from the Apple app store or the Google Play store. The survey was conducted from June 18 to June 24, 2017.

Next, the authors went through all the mobile websites and the mobile apps the libraries provide to check the mobile services offered. The authors used a specially designed survey to collect data about each library's mobile website and app (see table 1). The procedure of survey content analysis was conducted between June 25 and July 24, 2017, with the examination of each library's services taking approximately 30 minutes.

Finally, for those libraries that had no mobile websites or mobile apps found through the website visits, the authors made interview requests to staff librarians via their online reference services such as live chat, web form and email. An additional purpose of this step was to confirm the accuracy of the survey data collected from website visits. The survey was conducted from July 22 to August 3, 2017.

\section{RESULTS AND ANALYSIS}

Results from the examination of mobile website visits, content analysis, and librarian interviews revealed what services US urban libraries provided as mobile services, how they were provided, and which were commonly provided.

\section{How Many Libraries Provide Mobile Services?}

Over $83 \%$ of US urban libraries have developed their own mobile websites (see figure 1) for communities they serve. The mobile website is currently the most popular service platform for mobile users. 


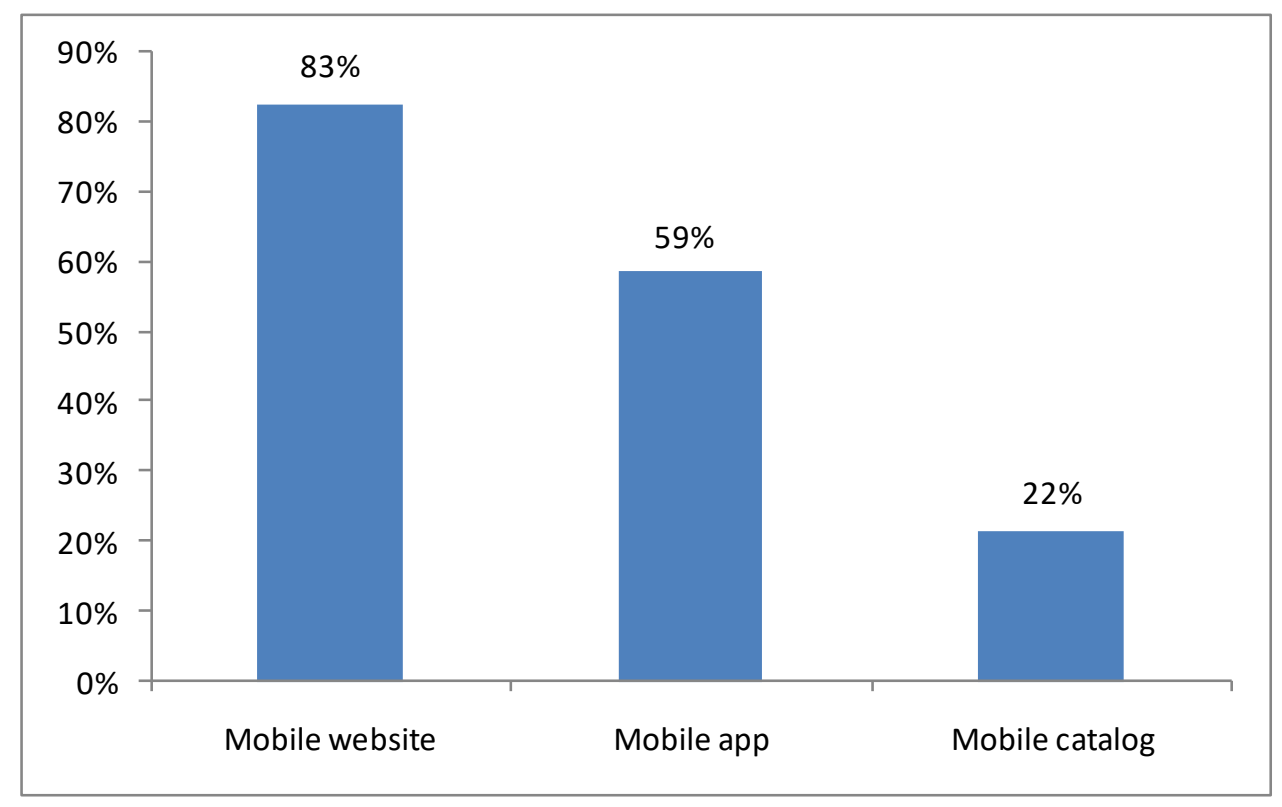

Figure 1. Types of mobile services provided by libraries.

Promisingly, each test of these websites through the authors' mobile devices, either smartphones or tablets, confirmed that all the study subjects can be accessed $100 \%$ of the time. These library websites, however, are not entirely built specially for mobile devices. While the majority of urban libraries have transformed their desktop websites into mobile sites with proper responsive design, about $17 \%$ are just smaller versions of their desktop websites (see figure 2).

A responsive mobile website can react or change according to the needs of the users and the mobile device they're viewing it on to achieve a good layout and content display. Here, text and images change from a three-column to a single-column layout, and unnecessary images are hidden. The web address of a responsively designed mobile website is the same as the desktop website. Responsive design is described as a long-term solution for addressing both designers' and users' needs. ${ }^{22}$

The survey found that $59 \%$ of libraries now have apps. Our analysis of the earliest version of apps records indicate that Los Angeles Public Library was the first to use an app, in August 2010.

Mobile apps have advantages and disadvantages compared to mobile websites, and many libraries compared them and chose between the two. Skokie (Illinois) Public Library, as of October 2015, is no longer supporting the library's mobile app because they claim the library's website offers a better mobile experience. They also offer an easy access solution like that for a mobile app, with a message displayed to users: "Miss having an icon on your home screen? Bookmark the site to your home screen and you'll have an icon to take you directly to this site." 


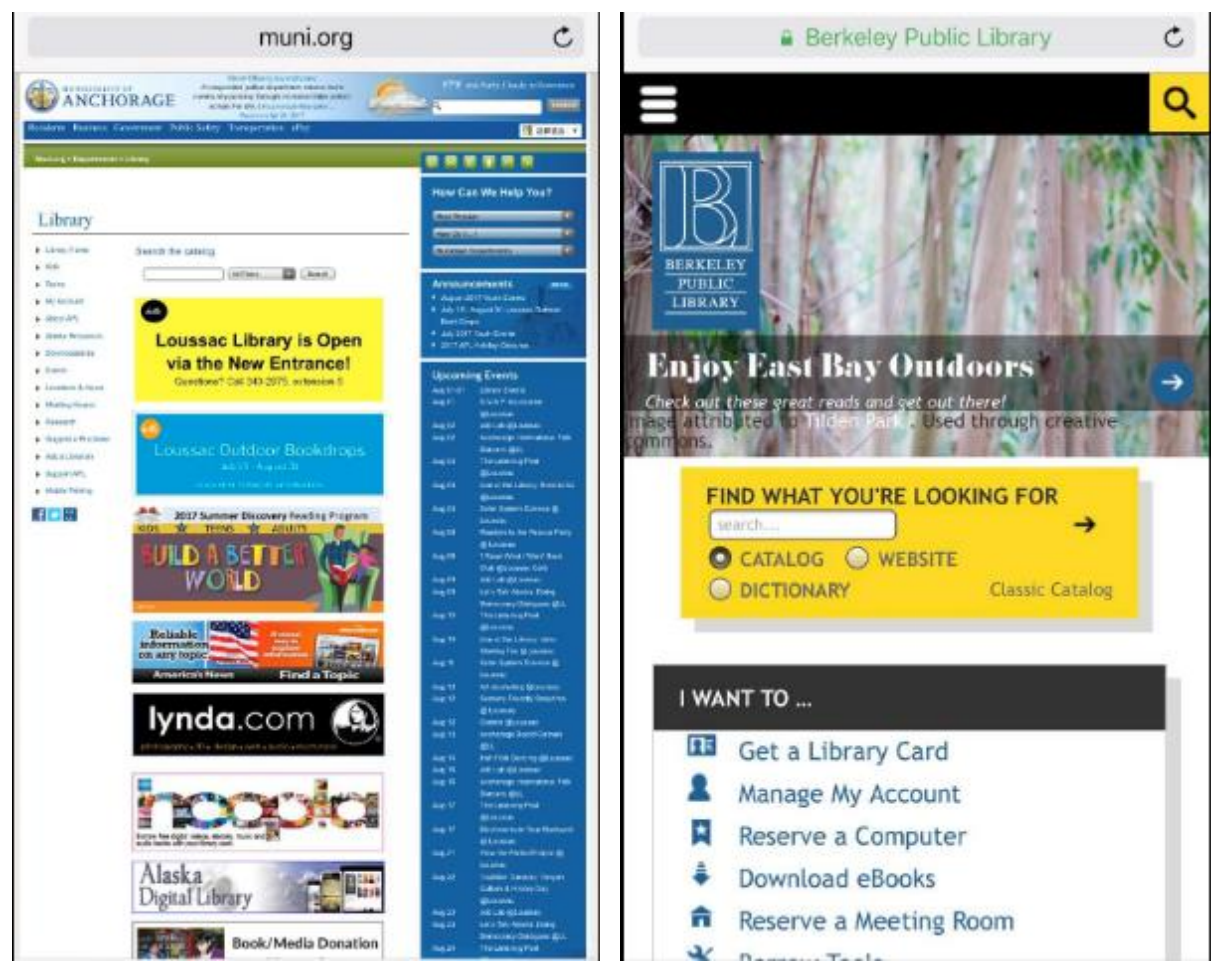

Figure 2. The smaller versions of the desktop website and the specially designed mobile website The proportion of libraries providing mobile catalog services is only $22 \%$.

Libraries can use multiple options to create one or more mobile service platforms. Nearly half (46\%) of US urban libraries have both mobile websites and mobile apps. According to the survey, $95 \%$ of libraries have at least one mobile website, mobile catalog, or mobile app. A survey the authors conducted in April 2014 found that only 81\% of the urban libraries had at least one mobile website, mobile catalog, or mobile app (see figure 3). Clearly, libraries are paying increasing attention to mobile services, and providing mobile services has become the unavoidable choice of libraries nowadays.
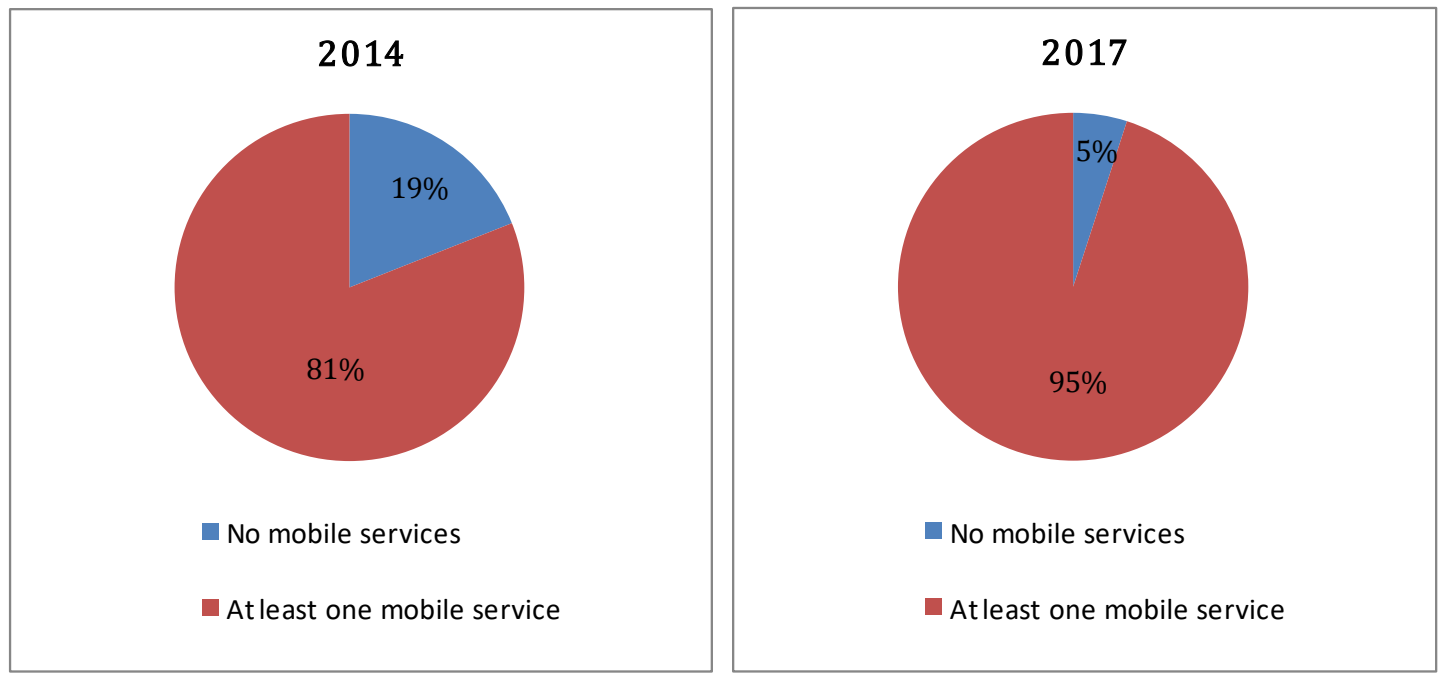

Figure 3. Changes in the proportion of libraries that provide mobile services from 2014 to 2017. 


\section{What Content do the Mobile Websites Offer?}

Through mobile website visits and content analysis, it was found that some types of information are available at all libraries, including "Account login," "Events," "Locations and hours," "Contact us," and "Social media" (see figure 4).

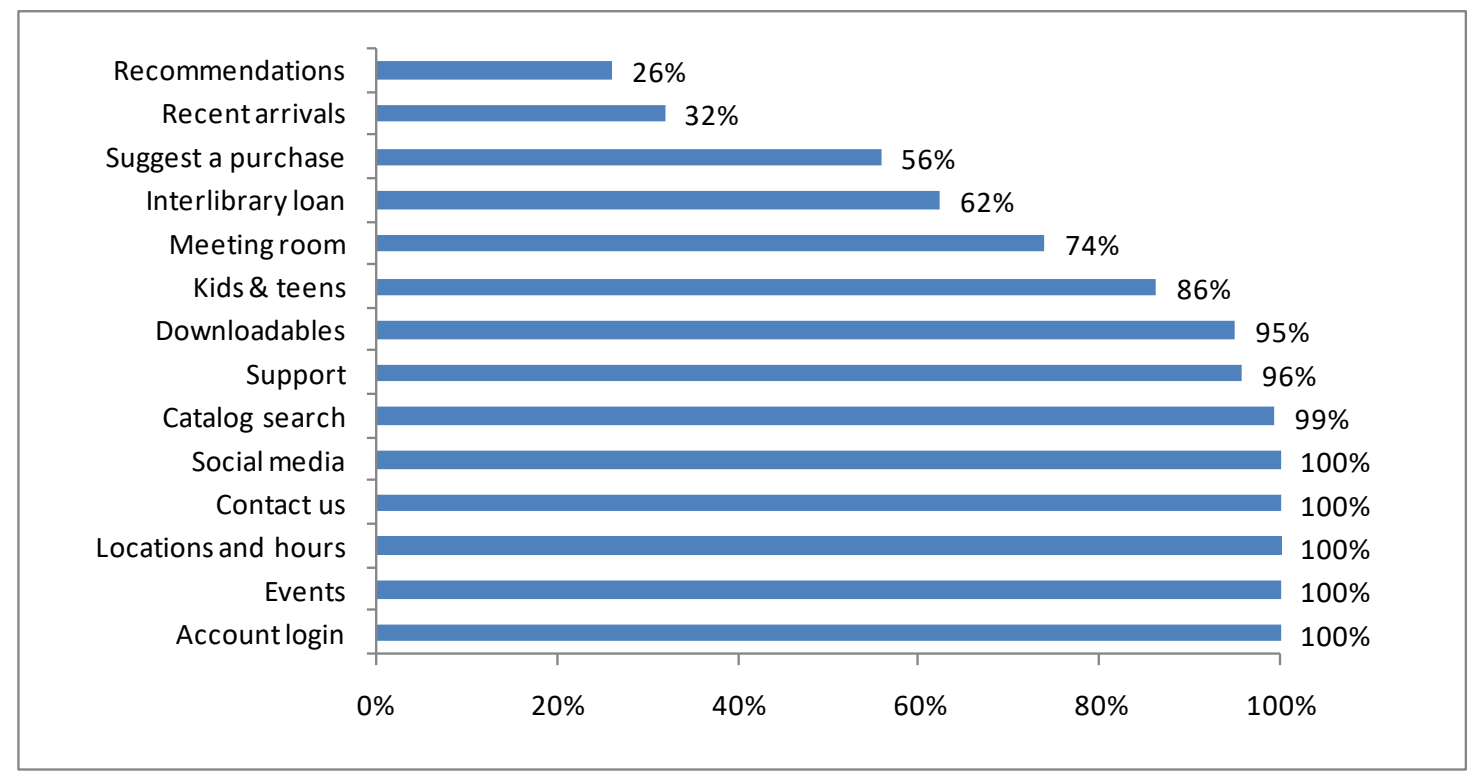

Figure 4. Components of mobile websites

The proportion of library mobile sites that offer "Support" and "Downloadables" is 96\% and 95\%, respectively. Among them, "Support" generally includes donations to the library foundation, donation of books and other materials, and providing volunteer services; "Downloadables" generally include e-books, e-magazines, and music. A total of $86 \%$ of the urban libraries set up "Kids" and "Teens" sections, providing specialized information services, such as storytime, games, events, book lists, homework help, volunteer information, and college information. A majority $(62 \%)$ of libraries provide interlibrary loan information on mobile websites, but one library, Palo Alto (California) City Library, no longer offers the costly Interlibrary loan service as of July 2011. More than half (56\%) of the libraries set up a "Suggest a purchase" function and generally ask readers to provide title, author, publisher, year published, format, and other information in web form. Some libraries display "Recommendations" (26\%) on their mobile websites. Denver Public Library has a special column recommending books for children and teenagers and offers personalized reading suggestions: "Tell us what you like to read and we'll send you our recommendations in about a week."

Many mobile websites will pop hints to the libraries' mobile apps and link to the Apple app store or the Google Play store after automatically identifying the user's mobile phone operating system. This is helpful for promoting the use of the libraries' apps, and it also provides great convenience for users. 


\section{What Content do the Mobile Apps Offer?}

The content of mobile websites in libraries is basically the same, but the content of their mobile apps varies widely. The reason is that the understanding of the various libraries about the functions an app should offer differs from one library to another. Some of these apps were designed by software vendors, such as Boopsie, SirsiDynix, and BiblioCommoms, but some were designed by the libraries themselves, leading to the absence of a uniform standard or template for the app design.

Survey results show that only "Account login" and "Catalog search" are available in all apps (see figure 5). "Locations and hours" accounts for a high proportion of apps at 96\%. The "Locations" feature in many libraries apps, with the help of GPS, helps users find their nearest library location.

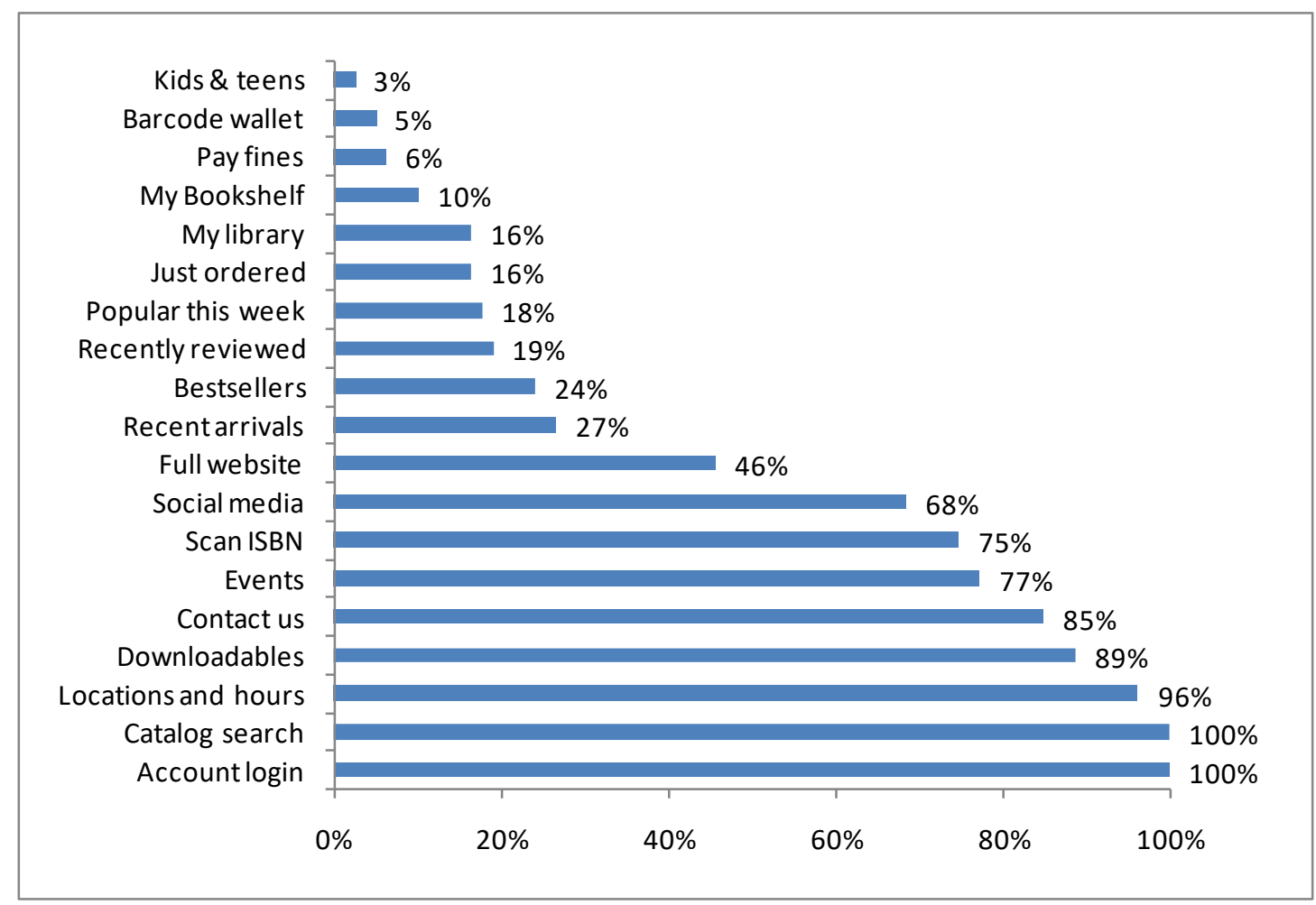

Figure 5. Components of mobile apps

About 85\% of apps provide "Contact us." Click "Contact us" in Poudre River Public Library District and some other libraries' apps, and you can directly call the library or send text messages via email. "Scan ISBN" is a unique feature of mobile apps, and 75\% of apps provide this functionality. If a library user finds a book they need in a bookstore or elsewhere, they can scan the ISBN to can see if that book is in the library's collection.

Apps designed by BiblioCommoms all have "Bestsellers", "Recently Reviewed", "Just Ordered" and "My library" (See chart Figure 6). In "My library," the "Checked Out" section contains red alerts for "Overdue," yellow alerts for "Due Soon," and "Total items." The "Holds" section contains "Ready for pickup," "Active holds," and "Paused holds." The "My Shelves" section contains "Completed," "In Progress," and "For Later." In this way, users can clearly see the details of the books they have 
borrowed and intend to borrow. Apps designed by Boopsie generally have "Popular this week" to tell users which books have been borrowed more recently.

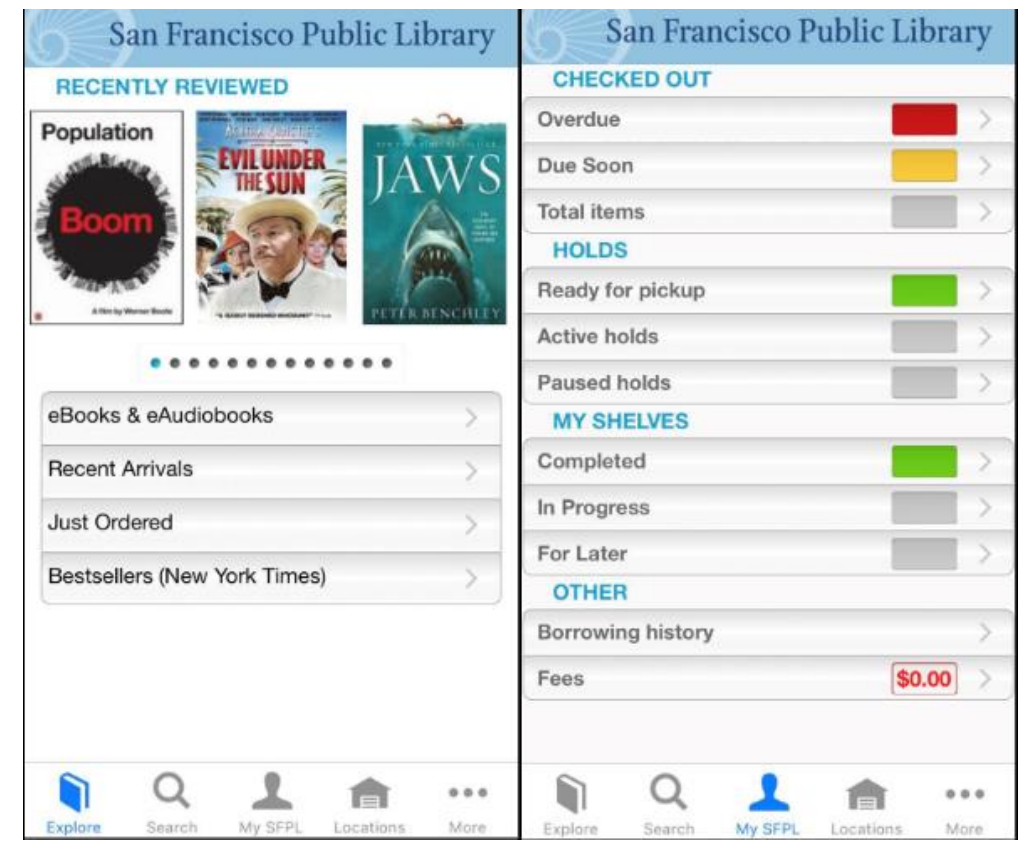

Figure 6. An app designed by BiblioCommoms.

Only 3\% of apps have "Kids" and "Teens" sections, which differs greatly from the percentage of mobile websites that offer those sections (86\%).

\section{What Mobile Reference Services do Libraries Provide?}

According to the survey, the most common way for US urban libraries to provide mobile reference service is a web form, which is available in $86 \%$ of surveyed libraries (see figure 7). Related to "Call us," a web form has the advantage of being independent from the library's working hours. Although users fill out and submit a web form, it is similar to email and, generally, librarians respond to the user's e-mail address, but it does not require users to enter their own email system, as they only need to fill in the content required by the web form. Therefore, it is more convenient to use. The authors believe that providing only an email address is not mobile reference service. The survey found that $6 \%$ of libraries do not have mobile reference services. 


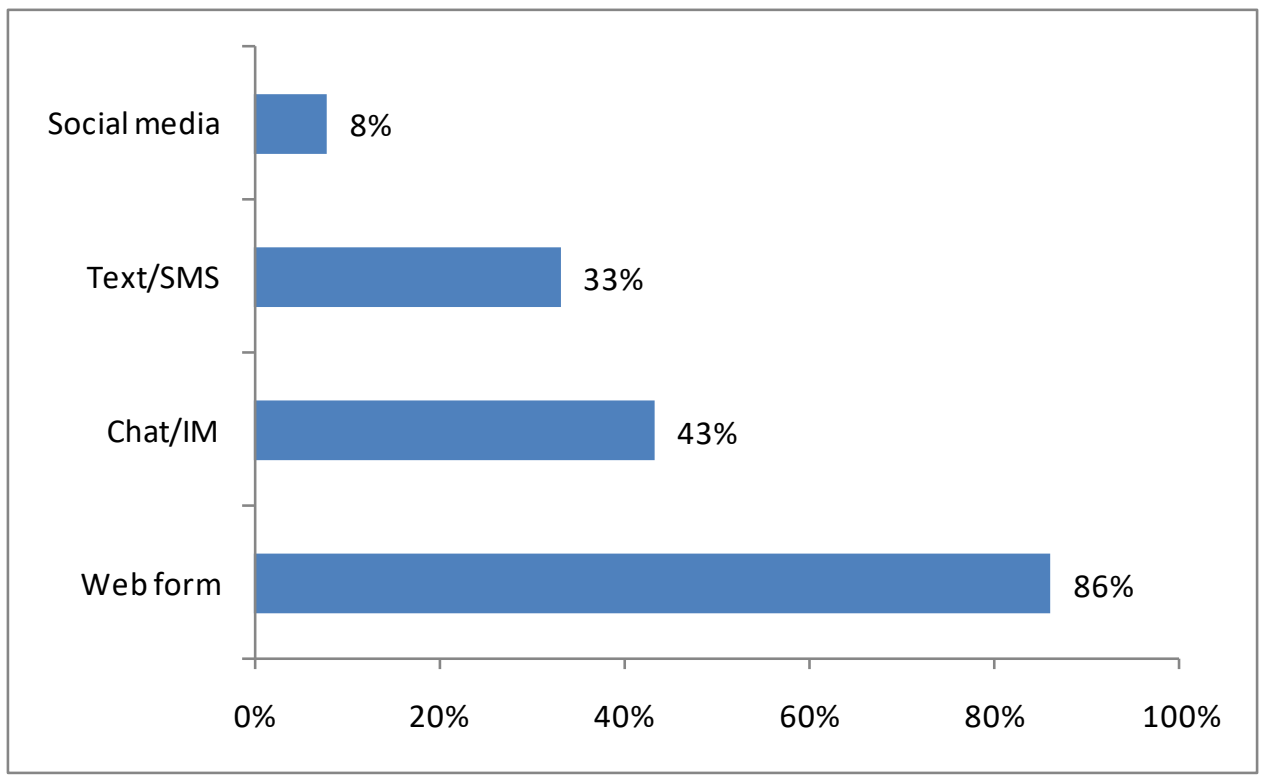

Figure 7. Mobile reference services provided by libraries.

Currently, 43\% of libraries offer chat and instant messaging (IM) services, which allow users to communicate with librarians instantly. For example, when Gwinnett County (Georgia) Public Library's mobile website is visited, an "Ask Us" dialog box appears in the upper right corner of the site, which allows visitors to chat with librarians. Outside of the library's work hours, the box displays "sorry, chat is offline but you can still get help" (see figure 8). The County of Los Angeles Public Library provides four options for IM. They are AIM, Google Talk, Yahoo! Messenger, and MSN Messenger.

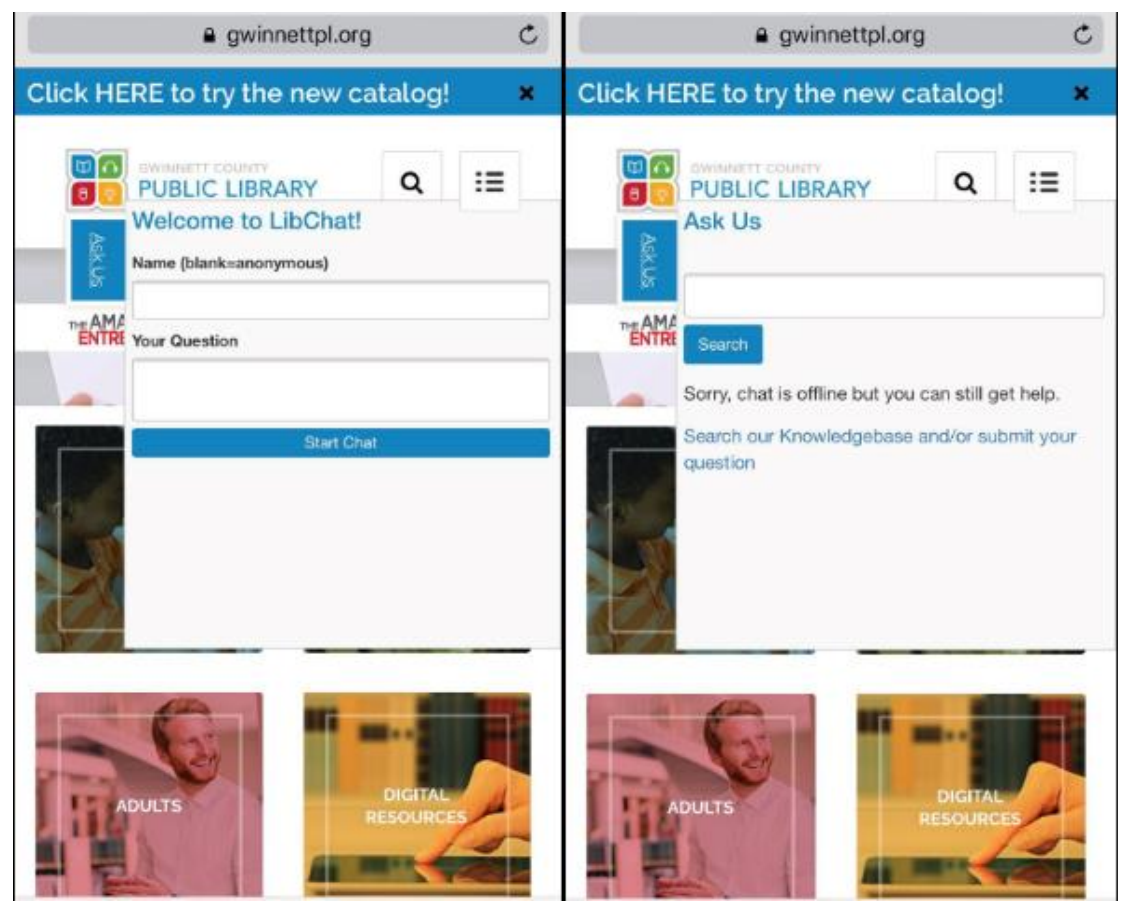

Figure 8. “Ask Us” on Gwinnett County Public Library’s mobile website 
All the Florida urban libraries surveyed offer reference services via the web form, chat, and text because an "Ask a Librarian" service administered by the Tampa Bay Library Consortium provides Florida residents with those mobile reference services.

The survey shows that only $8 \%$ of the libraries provide social media reference service in "Ask a librarian." The social media that provides reference service is either Facebook or Twitter. In fact, $100 \%$ of libraries have social media, and $100 \%$ of libraries have Facebook and Twitter, but most libraries do not use them to provide reference services.

\section{What Social Media do the Libraries Use?}

Survey results showed that $100 \%$ of mobile websites display links to their social media, usually in the prominent position of the front page of the websites; $68 \%$ of apps have social media links.

Facebook and Twitter are social media leaders, and now all libraries' mobile websites have both (see figure 9). The survey conducted in 2014 showed that Facebook and Twitter had the highest occupancy rate, but only $61 \%$ of libraries offered Facebook and 53\% offered Twitter. It is obvious that libraries have made great progress in the last three years in the application of social media.

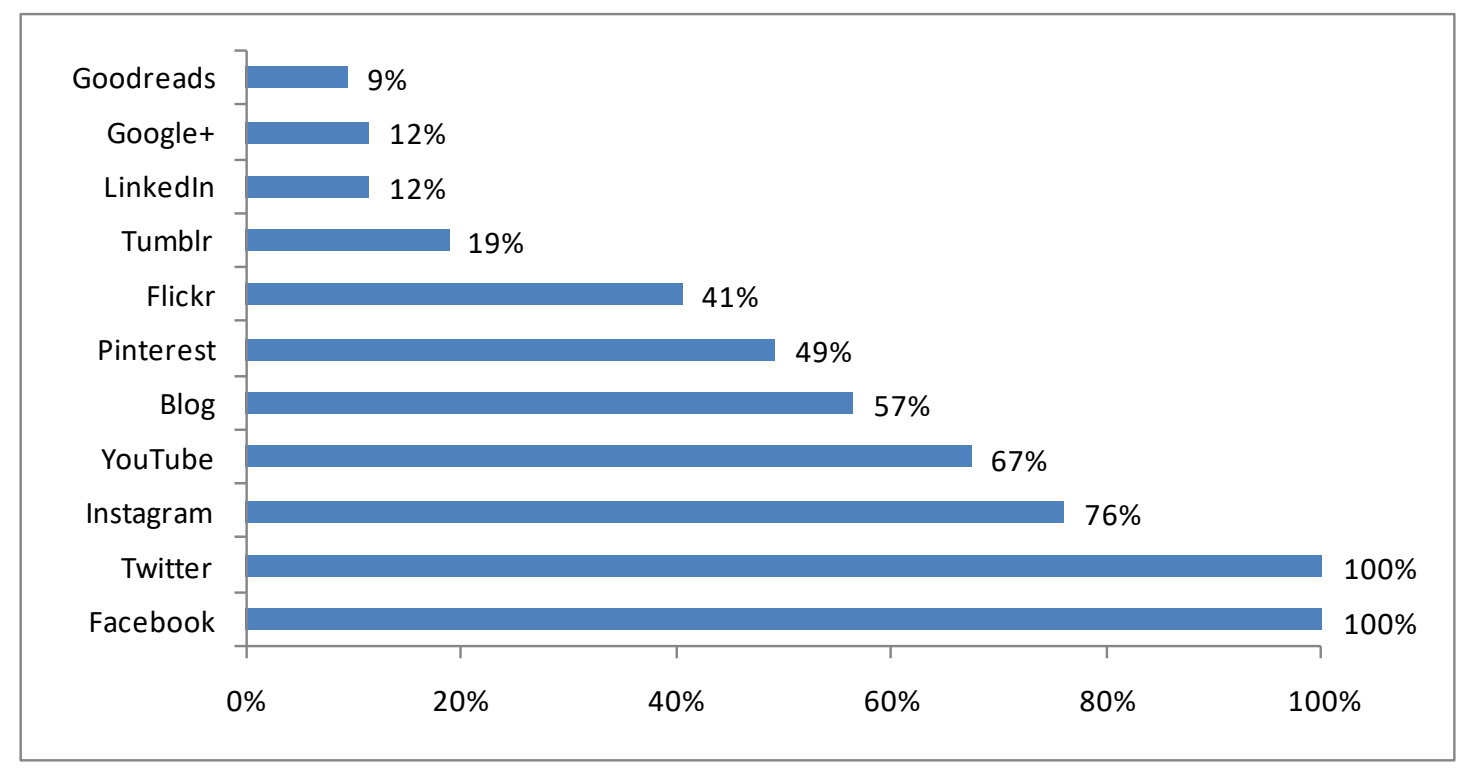

Figure 9. Social media being used by libraries.

Instagram and Pinterest are both photo social media, and they are used $76 \%$ and $49 \%$, respectively. As the leading social media in the video field, YouTube is used by $67 \%$ of libraries.

\section{What Mobile Reservation Services do Libraries Provide?}

Mobile reservation services were found in 78\% of all libraries' mobile services. A majority (62\%) of the libraries allow online reservation of a meeting room via web form or other forms, and $14 \%$ allow reserving a study room (see figure 10). Some libraries only reserve a study or meeting room via phone. 


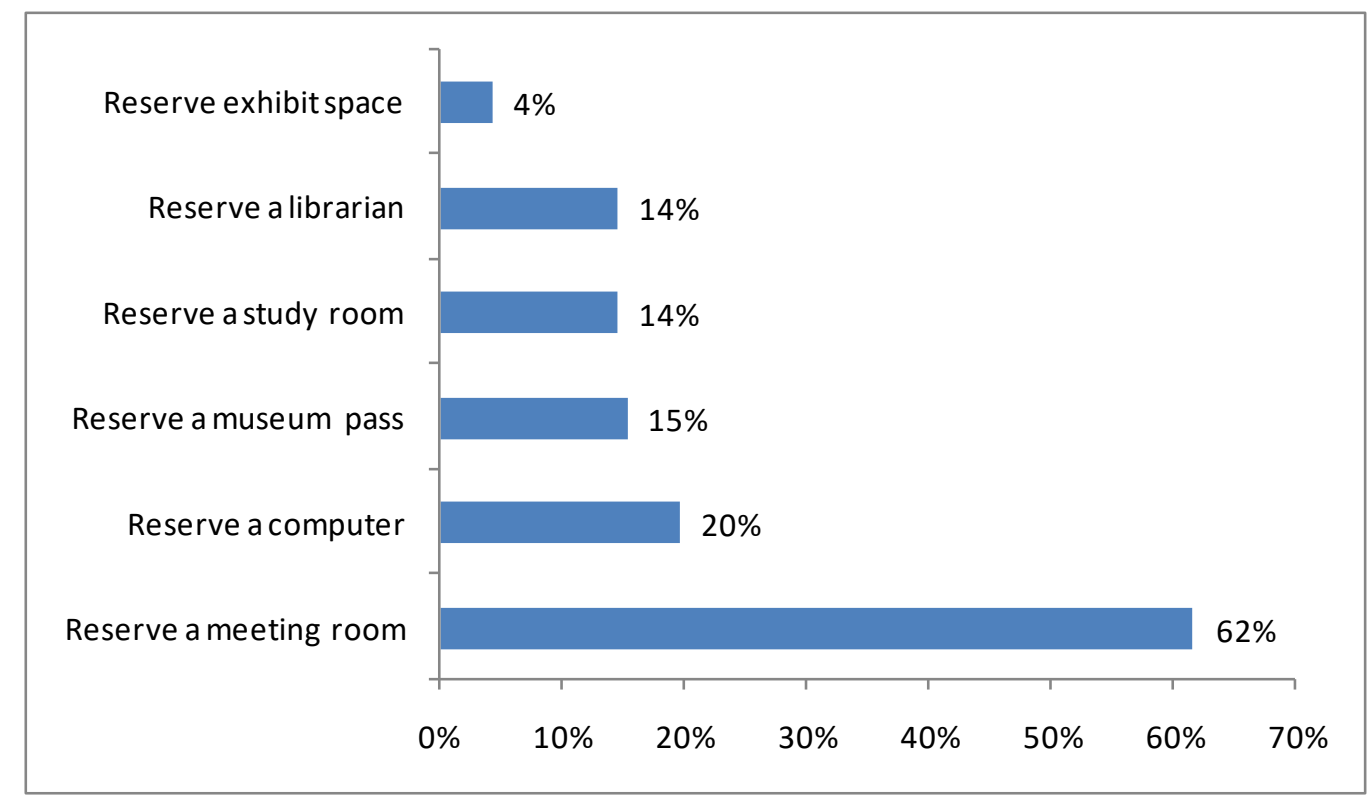

Figure 10. Mobile reservation services provided by libraries.

A few libraries provide instant online access to free and low-cost tickets to museums, science centers, zoos, theatres, and other fun local cultural venues with Discover \& Go. A total of $14 \%$ of the libraries provide "reserve a librarian" service, allowing patrons to reserve a free session with a reference librarian or subject specialist at the library. In addition, several libraries, such as Pasadena Public Library, allow reserving of exhibit space.

\section{How Many Libraries Provide Mobile Printing?}

Mobile printing services allow patrons to print to a library printer from outside the library or from their mobile device. Patrons' print jobs are available for pick up at the library. Already, $43 \%$ of the libraries provide mobile printing service (see figure 11). It is expected that more libraries will provide this service.

To print from a mobile device, patrons need to download an app that supports mobile printing. PrinterOn is the more commonly used app, which has been used by Oakland Public Library, and San Mateo County (California) Libraries, and others. However, San Diego Public Library uses the Your Print Cloud print system, and Santa Clara County (California) Library uses Smart Alec.

San Mateo County Libraries offers wireless printing from smartphones, tablets, and laptops at all of its locations, and its wireless printing includes mobile printing, web printing, and email printing.

In addition, 14\% of libraries offer wireless printing services but do not provide mobile printing services. For example, Live Oak Public Libraries in Savannah, Georgia, states that printing from laptops ( $\mathrm{PC}$ and $\mathrm{Mac}$ ) is available in all branches, but they don't have apps that support printing from tablets or mobile phones. 


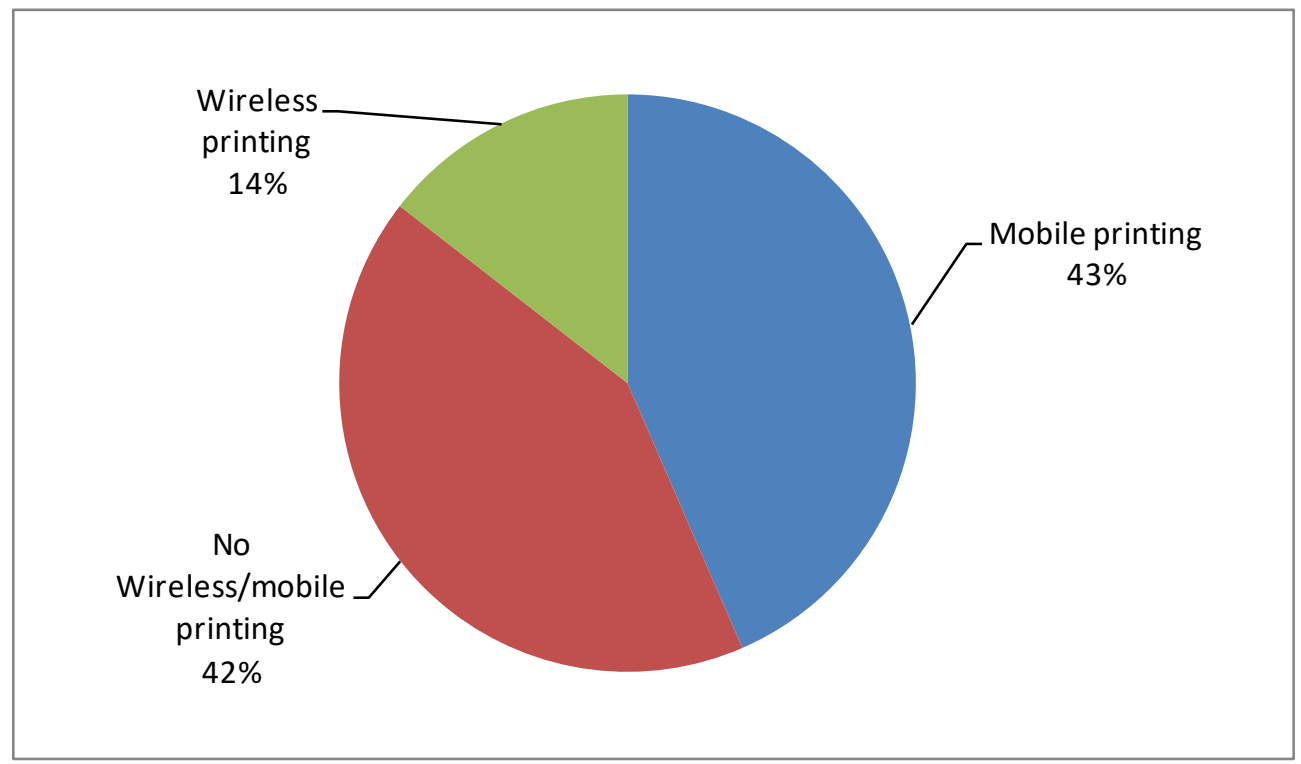

Figure 11. The proportion of libraries that offer mobile printing.

\section{What Apps or Databases do Libraries Provide for Patrons?}

Four main software programs found to be used to display e-books of the surveyed libraries are Overdrive (93\%), Hoopla (64\%), Tumblebook (61\%), and Cloud Library (48\%). For audiobooks, Overdrive (93\%) and Hoopla (64\%) are the most popular; oneclickdigital is used by $48 \%$. Most libraries (74\%) use Zinio for e-magazines, and 48\% use the music software Freegal. Overdrive is the most common application in libraries (see table 2).

Table 2. The proportion of apps or databases being used in libraries.

\begin{tabular}{|l|c|l|c|}
\hline $\begin{array}{l}\text { Apps or } \\
\text { Databases }\end{array}$ & $\begin{array}{l}\text { \% of Libraries } \\
\text { Providing }\end{array}$ & Apps or Databases & $\begin{array}{l}\text { \% of Libraries } \\
\text { Providing }\end{array}$ \\
\hline Overdrive & 93 & World Book & 46 \\
\hline NoveList & 79 & New York Times & 44 \\
\hline ReferenceUSA & 74 & MasterFILE & 43 \\
\hline Zinio & 74 & EBSCOhost & 43 \\
\hline LearningExpress & 69 & Flipster & 29 \\
\hline Gale Virtual & 68 & BookFlix & 28 \\
\hline Hoopla & 64 & Brainfuse & 22 \\
\hline Morningstar & 64 & Tutor.com & 17 \\
\hline Mango Languages & 61 & Safari & 17 \\
\hline TumbleBook & 61 & Driving-Tests.org & 16 \\
\hline Lynda.com & 57 & BiblioBoard & 12 \\
\hline WorldCat & 51 & Career Transitions & 12 \\
\hline Freegal & 48 & Axis 360 & 11 \\
\hline OneClick Digital & 48 & InstantFlix & 10 \\
\hline Cloud Library & 48 & Freading & 9 \\
\hline
\end{tabular}


The libraries provide users with various types of databases. Survey statistics show that the widely used databases include ReferenceUSA (business), Mango Languages (language learning), LearningExpress and Career Transitions (job and career), Lynda.com and Tutor.com (education), Morningstar (investment), World Book (encyclopedias), WorldCat (library resources worldwide), New York Times (newspaper articles), Driving-Tests.org (testing preparation), and Safari (technology).

\section{CONCLUSION}

This study shows that mobile services have become popular in US urban libraries as of summer 2017 , with $95 \%$ offering one or more types of mobile service. Responsive mobile websites and mobile apps are the main platforms of current mobile services. The US urban libraries are terribly striving to meet local community's remote access needs via new technologies.

Compared with desktop websites, mobile websites and apps for mobile devices offer services that are more accessible, smarter and interactive for local users. Some mobile websites automatically prompt the user to install the libraries' apps; many libraries' apps offer the "Scan ISBN" function, making it convenient for the user to scan a book title at any time to see if it is in the library's collection; "Location" provides GPS positioning and navigation services for users; "Contact us" can directly link telephone, text, and email.

Libraries are actively developing and adding more mobile services, such as mobile reservation services and mobile printing services. The development of mobile technology has provided the support for libraries to offer mobile services. A future world of users accessing services provided by the libraries at anytime, anywhere, and in any way is getting closer and closer.

\section{ACKNOWLEDGEMENTS}

This work was supported by grant no. 14CTQ028 from the National Social Science Foundation of China.

\section{REFERENCES}

${ }^{1}$ Jason Griffey, Mobile Technology and Libraries (New York: Neal-Schuman, 2010).

${ }^{2}$ Meredith Farkas, “A Library in Your Pocket," American Libraries no. 41 (2010): 38.

${ }^{3}$ American Library Association, "The State of America's Libraries 2017: A Report from the American Library Association," special report, American Libraries, April 2017, http://www.ala.org/news/sites/ala.org.news/files/content/State-of-Americas-LibrariesReport-2017.pdf.

${ }^{4}$ Mark Weiser, "The Computer for the 21st Century," Scientific American 265, no. 3 (1991): 94-104.

${ }^{5}$ Stefan Gessler and Andreas Kotulla, "PDAs as mobile WWW browsers," Computer Networks and ISDN Systems 28, no. 1-2 (1995): 53-59.

${ }^{6}$ Georgina Parsons, "Information Provision for HE Distance Learners using Mobile Devices," Electronic Library 28, no. 2 (2010): 231-44, https://doi.org/10.1108/02640471011033594. 
${ }^{7}$ Allison Woodruff et al., "Portable, but Not Mobile: A Study of Wireless Laptops in the Home," International Conference on Pervasive Computing 4480 (2007): 216-33, https://doi.org/10.1007/978-3-540-72037-9 13.

${ }^{8}$ Joan K. Lippincott, “A Mobile Future for Academic Libraries,” Reference Services Review 38, no. 2 (2010): 205-13.

${ }^{9}$ Rachel Hu and Alison Meir, "Mobile Strategy Report," California Digital Library, August 18, 2010, https://confluence.ucop.edu/download/attachments/26476757/CDL+Mobile+Device+User+R esearch final.pdf?version=1.

${ }^{10}$ Yan Quan Liu and Sarah Briggs, "A Library in the Palm of Your Hand: Mobile Services in Top 100 University Libraries," Information Technology \& Libraries 34, no. 2 (2015): 133-48, https://doi.org/10.6017/ital.v34i2.5650.

${ }^{11}$ Kitty Pope et al., "Twenty-First Century Library MUST-HAVES: Mobile Library Services,” Searcher 18, no. 3 (2010): 44-47.

${ }^{12} \mathrm{Hu}$ and Meir, "Mobile Strategy Report."

${ }^{13}$ Qian and Briggs, "A Library in the Palm of Your Hand."

${ }^{14}$ Kalah Rogers, "Academic and Public Libraries' Use of Web 2.0 Applications and Services in Mississippi," SLIS Connecting 4, no. 1 (2015), https://doi.org/10.18785/slis.0401.08.

15 Pope et al., "Twenty-First Century Library MUST-HAVES.”

${ }^{16}$ Lorraine Paterson and Low Boon, "Usability Inspection of Digital Libraries: A Case Study," Ariadne 63, no. 1 (2010): 11, https://doi.org/10.1007/s00799-003-0074-4. [website lists H. Rex Hartson, Priya Shivakumar, and Manuel A. Pérez-Quiñones as the authors]

${ }^{17}$ Todd Spires, "Handheld Librarians: A survey of Librarian and Library Patron Use of Wireless Handheld Devices," Internet Reference Services Quarterly 13, no. 4 (2008): 287-309, https://doi.org/10.1080/10875300802326327.

18 American Library Association, “Libraries Connect Communities 2011-2012," Last modified June, 2012, http://connect.ala.org/files/68293/2012.67B\%20PLFTS\%20Results.pdf.

${ }^{19}$ Barry Trott and Rebecca Jackson, “Mobile Academic Libraries,” Reference \& User Services Quarterly 52, no. 3 (2013): 174-78.

${ }^{20}$ Liu and Briggs, "A Library in the Palm of Your Hand."

${ }^{21}$ Bohyun Kim, “The Present and Future of the Library Mobile Experience," Library Technology Reports 49, no. 6 (2013): 15-28.

${ }^{22}$ Hannah Gascho Rempel and Laurie Bridges, "That Was Then, This Is Now: Replacing the MobileOptimized Site with Responsive Design," Information Technology \& Libraries 32, no. 4 (2013): 8-24, https://doi.org/10.6017/ital.v32i4.4636. 